Rev. salud pública. 14 (1): 156-168, 2012

\title{
Intestinal parasitism prevalence amongst children from six indigenous communities residing in Cali, Colombia
}

\author{
Prevalencia de parasitismo intestinal en menores de seis \\ comunidades indígenas residentes en Cali, Colombia
}

\author{
Mercedes Salcedo-Cifuentes ${ }^{1}$, Ofelia Florez ${ }^{1}$, Amparo Bermúdez ${ }^{2}$, \\ Luzmila Hernández $^{3}$, Cristina Araujo ${ }^{4}$ and María V. Bolaños ${ }^{1}$
}

\begin{abstract}
1 School of Bacteriology, Faculty of Health, Universidad del Valle, Cali, Colombia. mercysal2003@yahoo. com, oflorez79@hotmail.com, bogamai@hotmail.com

2 School of Public Health, Faculty of Health, Universidad del Valle, Cali, Colombia. amparitob@gmail.com 3 School of Nursing, Faculty of Health, Universidad del Valle, Cali, Colombia. luzmy1721@hotmail.com. 4 School of Medicine, Faculty of Health, Universidad del Valle, Cali, Colombia. criarau@yahoo.com.
\end{abstract}

Received $13^{\text {th }}$ April 2011/Sent for modification 10 ${ }^{\text {th }}$ February 2012/Accepted 22 ${ }^{\text {th }}$ February 2012

\section{ABSTRACT}

Objective Establishing the prevalence of intestinal parasitism in children aged 5 to 14 years of age from six indigenous communities residing in the city of Cali.

Methodology A cross-sectional, descriptive epidemiological study was carried out in six indigenous communities residing in the city of Cali; it consisted of making a direct serial and concentration coproparasitological examination of a randomly selected sample of fifty-seven 5 to 14 year-old children.

Results Of the 57 samples obtained, $84 \%$ of the children were infected with parasites; protozoa (98\%) predominated over helminths (16.7\%) and mixed parasitemia was found in $14.6 \%$ of the samples. Monoparasitism appeared in children over 10 years of age and biparasitism (10.4\%) and polyparasitism (52.1 $\%$ ) in children under 10 years of age. Regarding occult blood determination, $6 \%$ were observed to be positive in all the samples analysed; $4 \%$ of these results were associated with $E$. histolytica/dispar. The simple parasitism index (SPI) reflected a high degree of infestation amongst the children included in the study.

Conclusions The prevalence of intestinal parasitism in indigenous infants was higher than that reported nationally in the overall adolescent and school-aged children population in the same age group. Mono- and polyparasitism prevailed in the positive samples. The infestation load was not randomly distributed amongst the communities.

Key Words: Parasitic disease, helminthiasis, protozoan infection, prevalence, indigenous population (source: MeSH, NLM). 


\section{RESUMEN}

Objetivo Establecer la prevalencia de parasitismo intestinal en menores de 5 a 14 años de seis comunidades indígenas residentes en la ciudad de Cali.

Metodología Se llevó a cabo un estudio epidemiológico transversal en seis comunidades indígenas residentes en la ciudad de Cali, que consistió en realizar un examen seriado coproparasitológico a una muestra de menores entre 5 y 14 años elegida al azar.

Resultados De las 57 muestras, un total de 84 \% estaban infectados con parásitos; en los cuales predominaron los protozoarios (98\%) sobre los helmintos $(16,7 \%)$ y la presencia de enfermedades parasitarias intestinales mixtas fue del 14,6\%. El monoparasitismo se observe en los mayores de 10 años; en niños por debajo de los 10 años se observó el biparasitismo (10,4\%) y poliparasitismo (52,1\%). Con relación a la determinación de sangre oculta, un $6 \%$ de las muestras fueron positivas, $4 \%$ de esos resultados estaban asociados con E. histolytica/dispar. El índice de parasitismo simple refleja un alto grado de infestación en los menores incluidos en este estudio.

Conclusiones La prevalencia de parasitismo intestinal en menores de ascendencia indígena es mayor a la reportada en el orden nacional en menores escolares y adolescentes. Sobresalieron el mono y poliparasitismo en las muestras positivas. La carga de infestación no se distribuyó al azar entre las comunidades.

Palabras Clave: Enfermedades parasitarias, helmintiasis, infecciones por protozoarios, prevalencia, población indígena (fuente: DeCS, BIREME).

$\mathrm{P}$ arasitic infections continue to occupy an important place in the history of public health and human biology regarding some communities or regions around the world during the $21^{\text {st }}$ century, given their high prevalence and distribution, and because of the negative impact on population groups inhabiting tropical and subtropical areas nutritional and immune status. Infant and adolescent populations may be the most vulnerable and susceptible $(1,2)$. Such intestinal parasitism in children residing in urban and peri-urban areas is directly related to the specific geographical and ecological features of the places where such children live (3) and conditions regarding available basic sanitation, hygiene habits and their family nucleus $(4,5)$.

The World Health Organization (WHO) stated that 3.5 billion people were infected with intestinal parasites (52 \% world prevalence) in 1987 (6). Moreover, in 1999 Crompton (7) indicated that helminths were the most popular worldwide intestinal parasites accounting for 3,976 billion individuals infected, including Ascaris lumbricoides (1,472 billion 
infected individuals), unicarias (1,298 billion) and trichocephalus (1,049 billion). During the last 40 years $80 \%$ of the Colombian population has been infected by some kind of pathogen enteroparasite according to data presented by Galán (8), Alvarado (9) and Reyes (10). Such prevalence analysed by age range revealed that $83 \%$ of children aged 1 to 4 years and $90 \%$ of children aged 5 to 14 years were affected and that nematodes (roundworm), trichocephalus (whipworm), ancylostoma (hookworm), amoebae and Giardia were the most commonly occurring parasites.

The Meeting for Indigenous Peoples and Health held in 1993 reported that nearly 43 million indigenous people in the Americas have deficient living and health conditions (11). Colombia's indigenous population has one of the highest infant mortality rates around the world; an average of 250 in every thousand children in the indigenous communities of the Paeces in El Cauca, Awá Kwaikeres in Nariño and Embera in Antioquia die before reaching six years of age. The main cause of infant mortality is malnutrition, which makes children much more vulnerable to any type of disease (12). Infant malnutrition is often associated with intestinal parasitism depriving organisms of nutrients through different mechanisms related to enteropathogenic types.

A research project carried out by geneticists from the Universidad Javeriana in Bogota covering a good part of the country's indigenous and black population found that intestinal parasitic disease accounted for the most common finding in these communities in Pacific and Andean areas. The highest intestinal polyparasitism prevalence was found in the Coreguaje population (76.2 \%) followed by the Paeces (70.7 \%) (13).

No studies were identified regarding intestinal parasitism in children and adolescents from indigenous communities living in urban areas. A possible explanation would be that public healthcare management promotes supplying antiparasitic drugs without prior request for coprological tests to prevent iron deficiency, anaemia and absenteeism from school, as well as nutrition programmes.

Santiago de Cali is located in south-western Colombia. The climate is temperate and ocean breezes reach the city even though the western Andean mountain range blocks humid winds from the Pacific. Some historians and travellers visiting this area in the past reported on its particular characteristics 
when they stated, "the most ill of the department's towns, because besides being hot from noon on, there are winds that bring ailments that corrupt the body ..." (14).

Studies of soil from different parts of the city by last-semester students from the Universidad del Valle's (UniValle) Bacteriology and Clinical Laboratory programme have revealed a high prevalence of intestinal protozoa, helminth eggs and parasites from both humans and domestic animals (15). Bearing this city's characteristics in mind and lacking current parasite prevalence statistics for children aged 5 to 14 years living in indigenous communities in Cali, a group of interdisciplinary researchers from the Universidad del Valle's Faculty of Health set out to determine intestinal parasite prevalence and distribution in children from six indigenous communities residing in urban and suburban areas of the city.

\section{MATERIALS AND METHODS}

Kind of study and sample designThis was a descriptive design which measured intestinal parasite prevalence in children of indigenous descent. Sample size was calculated thus (16):

$$
N=\frac{z_{\alpha 2} P(1-P)}{i^{2}}
$$

where $p$ was expected parasite prevalence (19), $i$ was interval amplitude or precision (10\%) and $\mathrm{Z}_{\mathrm{a}}{ }^{2}$ was the study's confidence level (i.e. $95 \%$ ); this gave a sample size of 57 children.

Children were randomly selected from a list of indigenous children and adolescents aged 5 to 14 years old to complete the sample for each indigenous community. During such selection, children who did not wish to participate in the study or whose participation was not authorised by their parents or guardians were replaced by others from the same age-range and indigenous community until completing the sample for each indigenous council; this was carried out between March 20 ${ }^{\text {th }}$ and 22 ${ }^{\text {nd }}, 2010$.

Inclusion criteria

- Children between 5 and 14 years of age from six indigenous groups residing in the city of Cali;

- Indigenous children who had not shown symptoms of fever, abdominal pain, vomiting or diarrhoea within the last month; and 
- Indigenous children who reportedly were not taking or had not taken any type of antiparasitic drug or medication during the last three months.

Exclusion criteria

- Children not belonging to any of the indigenous councils considered in the study; and

- Children with symptoms of some symptomatology associated with parasitism.

Sample reception and processing

Sterile plastic containers were distributed which were labelled with the name and an assigned code to collect the samples; information and explanations were furnished to the indigenous authorities, the parents/legal guardians and the children during previously coordinated briefings with the governors from each council regarding how they were to collect and transport the stool samples to the collection sites. The collection and transportation guidelines followed pre-analytical standard operating procedures (SOP) previously drawn up by UniValle bacteriology students; the procedures had been reviewed and approved by the project's research professors. Six dates were programmed for receiving stool samples at the School of Bacteriology’s Parasitology Laboratory.

Two professors from the academic unit having active experience in clinical diagnosis, an expert professor in parasitology and an expert professor in quality control processed the samples in line with the following coproparasitological SOPs:

- Parasitological analysis (Fisher Diagnostics PROTOCOL* parasitology single-vial kits);

- Occult blood determination (Beckman Coulter Hemoccult II Ultra-Sensa protocol); andHelminth egg count: Kato-Katz quantitative method (BioManguinhos helm test protocol).Ethical considerationsEach child's legal guardian received a detailed explanation of the project and signed an informed consent form. The study was supported by the Universidad del Valle's Faculty of Health's Ethics Committee and was approved by each indigenous council authority included in the study. 
Statistical analysis

The pertinent information from an Excel database was transferred to SPSS version 17 software for statistical analysis. Percentages were calculated for qualitative variables; frequency distribution was used for quantitative variables and measurements of central tendency and dispersion were expressed by means, mediums and standard deviations. Cross- tabulations (2x2 tables) and Chi square (95\% CI) and Fisher tests were used to assess whether there were statistically significant differences amongst and within communities. A statistically significant difference was considered when $p<0.05$. Prevalence ratios were calculated with their respective 95 $\%$ confidence intervals. The Fager index was used for calculating affinity between pairs of species (17); the simple parasitism index (SPI) and corrected parasitism index (CPI) (18) were also calculated. ARGIS version 9.3 geo-referencing was used for locating the sectors of the city where the family nuclei of the children infected with parasitism included in the study were located.

\section{RESULTS}

The studied population's average age was $9 \pm 3$ years, $56.1 \%$ discreet, insignificant male predominance. Distribution according to age per council revealed that the Yanacona community had the highest proportion of children under 10 years of age (13/16), followed by the Nasa (7/13) and the Inga (6/13. Elementary school was the educational level reached by most children included in the study (64.3\%).

A macroscopic study of the 57 children's faeces revealed normal features in $84 \%$ of them whilst $16.7 \%$ had pathological faeces; diarrheal stools were the most frequent tab normal macroscopic characteristics (44 $\%)$ within the latter group and green stools (33\%) and pale and spongy stools (22\%) were also noted.

A total of $84 \%$ of the children were infected with parasites; protozoa (98 \%) were found to predominate over helminths (16.7 \%) along with the presence of mixed parasitemia in samples (14.6\%). Helminth parasitism was frequent in children from the Inga (23.1\%), Nasa $(23.1 \%)$ and Quichua (25\%) communities. Table 1 shows distribution by protozoan type and gender. 
Table 1. Distribution of the protozoa identified in stool samples from the children included in the study

\begin{tabular}{|c|c|c|c|c|c|c|c|c|c|c|c|c|c|c|}
\hline \multirow{2}{*}{ Council } & \multicolumn{2}{|c|}{ E. nana } & \multicolumn{2}{|c|}{ G. lamblia } & \multicolumn{2}{|c|}{ E. coli } & \multicolumn{2}{|c|}{ Ch. messnilii } & \multicolumn{2}{|c|}{$\begin{array}{c}\text { E. histolytica } \\
\text { /dispar }\end{array}$} & \multicolumn{2}{|c|}{ I. bütschlii } & \multicolumn{2}{|c|}{ B. hominis } \\
\hline & $\begin{array}{c}\text { Fem. } \\
(\%)\end{array}$ & $\begin{array}{c}\text { Male } \\
(\%)\end{array}$ & $\begin{array}{c}\text { Fem. } \\
(\%)\end{array}$ & $\begin{array}{c}\text { Male } \\
(\%)\end{array}$ & $\begin{array}{c}\text { Fem. } \\
(\%)\end{array}$ & $\begin{array}{c}\text { Male } \\
(\%)\end{array}$ & $\begin{array}{c}\text { Fem. } \\
(\%)\end{array}$ & $\begin{array}{c}\text { Male } \\
(\%)\end{array}$ & $\begin{array}{c}\text { Fem. } \\
(\%)\end{array}$ & $\begin{array}{c}\text { Male } \\
(\%)\end{array}$ & $\begin{array}{c}\text { Fem. } \\
(\%)\end{array}$ & $\begin{array}{c}\text { Male } \\
(\%)\end{array}$ & $\begin{array}{c}\text { Fem. } \\
(\%)\end{array}$ & $\begin{array}{c}\text { Male } \\
(\%)\end{array}$ \\
\hline Misak & 4 & 4 & 0 & 0 & 0 & 0 & 0 & 0 & 4 & 2 & 0 & 0 & 4 & 2 \\
\hline Inga & 8 & 6 & 0 & 2 & 6 & 4 & 0 & 0 & 2 & 0 & 0 & 2 & 8 & 6 \\
\hline Kofán & 0 & 2 & 0 & 0 & 2 & 0 & 0 & 0 & 0 & 0 & 0 & 2 & 2 & 2 \\
\hline Nasa & 8 & 16 & 4 & 6 & 6 & 13 & 2 & 2 & 19 & 10 & 6 & 6 & 6 & 10 \\
\hline Quichua & 0 & 4 & 0 & 0 & 2 & 0 & 0 & 0 & 0 & 2 & 0 & 2 & 6 & 4 \\
\hline Yanacona & 8 & 6 & 2 & 2 & 6 & 13 & 4 & 0 & 2 & 0 & 2 & 0 & 8 & 8 \\
\hline
\end{tabular}

Figure 1 shows parasitism distribution according to the number and class of parasitism, showing greater polyparasitism in children from Nasa communities (92.3\%), followed by the Yanacona (69.2 \%), Inga (53.8 $\%)$ and Misak (100 \%). When calculating the polyparasitism infestation: gender ratio, one girl was found to have polyparasitism for every three boys suffering polyparasitism.

Figure 1. Distribution of the type of parasitism in the samples studied

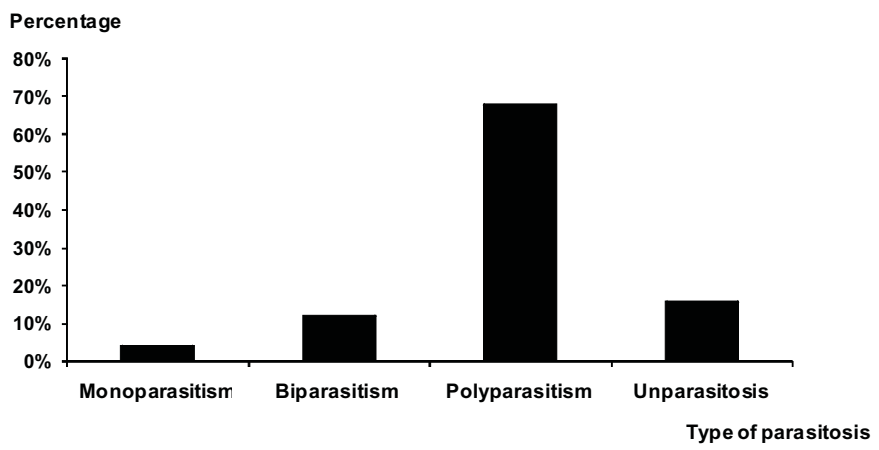

Monoparasitism appeared in children over 10 years of age and biparasitism (10.4\%) and polyparasitism (52.1\%) in children under 10 years of age, meaning that two children under 10 years of age were infected with protozoa for each child over 10 years of age. Mixed parasitism was present in $10 \%$ of the samples analysed.

The greatest affinity between species concurring in the same host was observed between E. coli and E. histolytica/dispar $(\mathrm{I}=0.42, \mathrm{t}=5.8)$, followed 
by $G$. lamblia and $E$. histolytical/dispar ( $\mathrm{I}=0.28, \mathrm{t}=6.27)$ among children from the Nasa community. The remaining pairs of species identified in faecal samples from 57 children from the six indigenous communities studied had a lower Fager index, such as A. lumbricoides and G. lambia; E. coli and Trichocephalus (in Quichua: $\mathrm{I}=0.16, \mathrm{t}=4.25$; Nasa: $\mathrm{I}=0.16, \mathrm{t}=4.25$ ).

Ascaris lumbricoides (8.3 \%) and Trichuris (10.4\%) were very similar concerning helminth prevalence in the studied population. Parasitic content analysis showed that $75 \%$ of the minors were severely infected and $25 \%$ were slightly infected.

Regarding occult blood determination, $6 \%$ of samples were seen to be positive; $4 \%$ of these results were associated with E. histolytical/dispar.

Geo-referencing regarding the place of residence for the children included in the study revealed children suffering biparasitism and polyparasitism to be concentrated in communes 3, 9, and 22.

Intestinal parasitism prevalence distribution in children aged 5 to 14 years old from indigenous ethnic groups per commune was concentrated in communes 3,18, and 19, characterised by their low socioeconomic level and poor conditions regarding the provision of healthcare services, drinking water and sewage systems.

The SPI (defined as the ratio between the number of positive samples or parasite-infected individuals (NPI) and sample size) reflected a high degree of infestation amongst the children included in the study (no statistically significant differences per indigenous community; $\mathrm{p}>0.05$ ). The corrected parasitism index (CPI) (reflecting the ratio between total number of parasites and the number of parasite-infected individuals) revealed that the number of parasites per child included in the study discriminated by ethnic group was very similar, except in Nasa children where the number of parasites per child was double compared to the other children (Table 2).

Table 2. Distribution of simple parasitism indices (SPI) and the corrected parasitism index (CPI) per indigenous community included in the study

\begin{tabular}{ccccccc}
\hline $\begin{array}{c}\text { Guámbianos } \\
(\%)\end{array}$ & $\begin{array}{c}\text { Inga } \\
(\%)\end{array}$ & $\begin{array}{c}\text { Kofan } \\
(\%)\end{array}$ & $\begin{array}{c}\text { Nasa } \\
(\%)\end{array}$ & $\begin{array}{c}\text { Quichua } \\
(\%)\end{array}$ & $\begin{array}{c}\text { Yanaconas } \\
(\%)\end{array}$ \\
\hline SPI & 100.0 & 100.0 & 100.0 & 100.0 & 80.0 & 100.0 \\
CPI & 3.2 & 3.4 & 3.0 & 7.8 & 3.2 & 3.3 \\
\hline CPI Mean: $0.040 ;$ Coefficient of variation: 0.305 & & &
\end{tabular}




\section{DISCUSSION}

Intestinal parasitism in infant and adolescent populations is a public health problem in tropical and developing countries; however, the pertinent surveillance has been relegated to the background and most interventions are mostly geared towards diagnosis, screening or monitoring. As healthcare personnel give little importance to it, this may be the cause for its low mortality rate and its effects being long-term (1). Parasite prevalence studies in Colombia are scarce. This research has evaluated intestinal parasite prevalence in a sample of 57 children aged 5 and 14 years old from six indigenous communities residing in Cali; the intestinal parasite prevalence found in the indigenous children included in the study was higher than that detected in the world-wide population without ethnic discrimination $(6,7)$. However, this prevalence was lower compared to national reports $(8,9)$. The few national reports would include National Morbidity Research (1965 and 1980) which revealed that helminthiasis caused by Ascaris lumbricoides affected $54 \%$ of the population in 1965, significantly decreasing by 1980 (34\%). This finding coincided with reports concerning Trichuris trichiura prevalence (50\% for 1965 and $37 \%$ for 1980). Entamoeba histolytica prevalence was $24 \%$ in the first report and decreased to $12 \%$ in the second report. On the contrary, Giardia lamblia increased its prevalence from 9.4 \% in 1965 to $21.4 \%$ in 1980 (19).

A study of Giardiasis and intestinal parasites' prevalence carried out in the city of Armenia in Colombia's Quindío department involved preschool children from homes in a state programme (20); it revealed 13\% prevalence for Giardia lamblia. However, given that it is the most prevalent pathogenic parasite in such children, most had no symptoms. This study referred to previous studies recommending the importance of conducting serial coprological tests thereby improving sensitivity by $50 \%$ when taking only one sample and by $90 \%$ with serial tests on non consecutive days, given the removal of intermittent cysts and trophozoitesis (20). Giardia lamblia prevalence in children from the six indigenous communities in the current study was significantly higher when comparing positivity amongst the three serial samples ( $\mathrm{X}^{2}$ test; $\mathrm{p}<0.05$ ), becoming significantly reduced when only one sample was considered.

Regarding parasite type prevalence in this study, $2 \%$ helminthiasis was seen in a biparasite sample (Ascaris lumbricoides and Trichocephalus) 
such data being lower than that reported in 2000 by the Colombian Institute of Health (19). These percentages were low compared to other studies on children in different parts of Colombia and even in international studies concerned with indigenous communities $(7,19,22-25)$.

By contrast with helminth prevalence, E. nana (a non-pathogenic amoeba) had the greatest prevalence in protozoa; this could have reflected continuous exposure to risk factors for infection at home and in the community, accentuated by increased transmission rate amongst children residing in the same household unit, schools and public or domestic areas where children play. The finding was significant regarding enteroparasite infection ecology, given that it is an indicator of parasite prevalence in such environments where children become concentrated for extended periods of time. This is why deparasitising programs are short-term prevention measures, thereby mitigating the risk or breaking transmission cycles. Colombian healthcare authorities must consider a monitoring system for such population group and habitat of the communities in question and for domestic groups running the risk of greater exposure to infection (26).

While enteroparasite prevalence studies in Colombia may be scarce, they are much more so regarding indigenous communities. Vital statistics regarding the health of communities residing in cities are lacking (much less so regarding those from rural areas). Geo-referencing the areas where children in the study lived whose stools were positive for enteroparasites showed that they lived in the city's sectors affected by poverty (tiers 1 and 2). This could have meant that poor household hygiene added to unsuitable housing, poor sanitation measures, deficient drinking water supply, lack of coverage and access to healthcare services for childhood controls and other socioeconomic and cultural factors constituted social risk factors for this disease $(22,24)$.

The above results contrasted with those of other studies concerning communities residing in urban areas where intestinal parasitism prevalence (27) in indigenous communities in Venezuela had over $80 \%$ prevalence, ten times higher than Colombian prevalence. Whilst they did not find statistically significant differences by gender and age, young people were the most affected, especially those under 10 years of age. When evaluating this prevalence by the number of species present in each host, it was found that they doubled polyparasitism figures from this study and, by contrast, protozoa 
were the most frequently occurring type of parasite (25). Studies carried out with indigenous communities in other Latin-American countries have also indicated high enteroparasitosis prevalence $(26,28)$. For example, intestinal parasitism is a public health problem in Peru and intestinal infectious diseases are amongst the 10 leading causes of death there (7.7\%). It is said that one in every three Peruvians carries one or more intestinal parasites; infection prevalence and intensity are associated with a greater risk of morbidity and tend to be higher in the school-age population (29).

Whilst 551 indigenous children were included in this study (6 indigenous councils), it did not cover indigenous children whose communities were not officially recognized by an indigenous council in Cali. These children's families lived on the hillsides; most lived in communes 3, 9 and 22.

Intestinal parasitism's impact on children and adolescents living in indigenous communities is high because healthcare opportunities are lower than for non-indigenous children. In countries like Colombia, where there is a lack of updated statistics regarding these communities' health conditions, such public health non-surveillance could have a negative impact on children's health and on their potentially healthy years of life.

Children's and adolescents' decreased growth results from intestinal parasitism thereby affecting proper cognitive and motor development; it can lead to the onset of chronic anemia which also affects scholastic performance (30). This disease's high prevalence in indigenous children may impose a high economic load on their family nuclei and increase healthcare system costs for indigenous communities.

It is undeniable that certain factors could be influencing perpetuating this prevalence, like life-style, poor or insufficient nutritional hygiene, precarious living conditions, lack of sanitation or inadequate sanitation services, lack of drinking water or poor water supply or lack of hygiene, meaning that these factors should be explored regarding these children and their families to identify the most affected communities and develop educational strategies to empower communities to reduce a pathology which is greatly affecting their children and which is easily preventable. Children should be screened to identify polyparasitism carriers, i.e. they should be periodically monitored and treated to reduce contamination levels within these communities. 
The combined impact of several intestinal parasites species is greater than that produced by individual parasites; the high frequency noted regarding those infected by polyparasitism is of concern for these communities due to the risk of serious conditions arising involving resistance and invasive forms, accompanied by their pathological consequences for the affected population. The results suggested the need to broaden studies by integrating scientific and aboriginal knowledge to guarantee sanitation programme efficiency and explore parasitism level in the environment where the children and family carry out their daily activities

Acknowledgments: We would like to thank the governors and indigenous authorities from the Kofan, Misak, Inga, Nasa, Quichua, and Yanacona Indigenous Councils, as well as the council members who supported the project within each council. This work was financed by the Universidad del Valle’s Research Division (grant 1636 / 2008).

\section{Conflict of interests: none}

\section{REFERENCES}

1. Savioli L, Bundy D, Tomkins A. Intestinal parasitic infections: A soluble public health problem. Trans R Soc Trop Med Hyg. 1992;86:353-354.

2. Pan American Health Organization. La salud en las Américas [Internet]; II: 403 - 418. Washington, DC: PAHO, 1998. Available at: URL: http://www.paho.org/Spanish/SHA/ HIA_1998ed.htm. Accessed: January 2010.

3. Soriano SV, Barbieri LM, Piarengeli NB, Giayetto AL, Manacorda AM, Castronovo E, et al. Intestinal parasites and the environment: frequency of intestinal parasites in children in Neuquén, Patagonia, Argentina. Rev Latinoam Microbiol. 2001;43: 96-101.

4. Taus MR, Gasparovic A, Piaggio O, Goldaracena C, Giacopuzzi M, Piaggio R, et al. Prevalence of Giardia lamblia, its detection in water and its relationship with environmental factors in Gualeguaychu, Argentina. Bol Chil Parasitol. 1998; 53:88-92.

5. Gamboa MI, Basualdo JA, Kozubsky L, Costas E, Cueto, Rua E, Lahitte HB. Prevalence of intestinal parasitosis within three population groups in La Plata, Argentina. Eur J Epidemiol.1998; 14: 55-61.

6. World Health Organization. Prevention and control of intestinal parasitic infections. Geneva: WHO;1987. Technical report series N749.

7. Crompton D. How much human helminthiasis is there in the world?. J Parasitol. 1999; 85: 397-403.

8. Galán R, Agualimpia C, Corredor A, Cáceres E. Investigación Nacional de Morbilidad. Parasitismo intestinal. Bogotá, Colombia: Ministerio de Salud Pública, Ascofame; 1969.

9. Alvarado B, Vásquez L. Determinantes sociales, prácticas de alimentación y consecuencias nutricionales del parasitismo intestinal en niños de 7 a 18 meses de edad en Guapi, Cauca. Biomédica. 2006; 26: 82-94.

10. Reyes P, Agudelo C, Moncada L, Cáceres E, López C, Corredor A, et al., Desparasitación masiva, estado nutricional y capacidad de aprendizaje de una comunidad rural. Rev. Salud Publica (Bogotá). 1999; 1: 255-264.

11. PAHO. Resolution V of the Meeting of Indigenous Peoples and Health. Winnipeg: PAHO; 1993. Document CD37/20. 
12. Tabares E. Ciencia al día AUPEC. Población indígena, en riesgo de desaparecer. Cali: Universidad del Valle. 2004.[Internet]. Available at: http://aupec.univalle.edu.co/ informes/mayo97/boletin37/indigena.html. Accessed: January 2010.

13. Pontificia Universidad Javeriana, Terrenos de la Gran Expedición Humana, Serie Reportes de Investigación. 1994; 3: 32.

14. Friede J. Colección de documentos inéditos para la Historia de Colombia, T. X, Academia colombiana de Historia. Bogotá; 1960. p. 94.

15. Carrejo G, Yara M. Presencia de geohelmintos en algunas zonas verdes de las comunas 11, 17 y 19 de la Cuidad de Santiago de Cali, Colombia [Internet]. Available at http:/l uvsalud.univalle.edu.co/pdf/simpsios/decimo/Salon_201/8carrejo.pdf. Accessed: January 2010.

16. Martínez-Bencardino C. Muestreo. Bogotá: Ecoe; 1984.

17. Fager E. Determination and analysis of recurrent groups. Ecology. 1957; 38: 586-95.

18. Brower J, Zar J. Field and laboratory methods for general ecology. WM Brown Company Publishers: USA;1977. p 194.

19. Corredor A, Arciniegas E. Parasitismo Intestinal. Instituto Nacional de Salud. Santafé de Bogotá; 2000

20. Giraldo-Gómez JM, Lora F, Henao L, Mejia SH, Gómez-Marín JE. Prevalencia de Giardiasis y parasites intestinales en preescolares de hogares atendidos en un programa estatal en Armenia, Colombia. Rev. Salud Pública (Bogotá). 2005; 7(3):327-338.

21. Botero J, Castaño A, Montoya M, Hurtado M, Ocampo N, Agudelo G, et al., Anemia por deficiencia de hierro y su asociación con los parásitos intestinales, en escolares y adolescentes matriculados en instituciones oficiales y privadas de Medellín, 19971998. Acta Med Col. 2002; 27 (1): 7-14.

22. Alvarado BE, Vásquez LR. Determinantes sociales, prevalencia y consecuencias sociales del parasitismo intestinal en población lactante en Guapi, costa Pacífica Caucana. Biomédica. 2003; 23: 84-85.

23. Ariza YJ, Sánchez CA, González AM, Ayala JF, Peñaranda M, Castro JI, Lizarazo WF. Estado de las parasitosis intestinales en la población escolar de la Esmeralda, Arauquita, Colombia, en Junio de 2002. Biomédica. 2003; 23: 94.

24. Navone GT, Gamboa MI, Oyhenart EE, Orden AB. Parasitosis intestinales en poblaciones Mbyá-Guaraní de la Provincia de Misiones, Argentina: aspectos epidemiológicos y nutricionales. Cad. Saúde Pública. 2006; 22(5): 1089-1100.

25. Devera R, Finali M, Franceschi G, Gil S, Quintero O. Elevada prevalencia de parasitosis intestinales en indígenas del Estado Delta Amacuro, Venezuela. Rev Biomed. 2005: 16:289-291.

26. Anacona A, Cardona MI, Tunubala. Estudio de Caracterización de Pueblos Indígenas:Kofán Misak-Guámbianos, Quichuas, Ingas, Yanaconas, Nasas habitantes de Santiago de Cali. Informe del proyecto: Asistencia Técnica para la Implementación de la Política Pública Indígena en Santiago de Cali; April $12^{\text {th }} 2010$ [Internet]. Available at www.cali. gov.co/descargar.php?id=27981. Accessed: January 2010.

27. Guevara R, Volcan G, Godoy G, Medrano C, González R, Matheus L. Parasitismo intestinal en cuatro comunidades indígenas del estado Bolívar. Cuad Geog Med Guay. 1986 1:93-6.

28. Díaz Al, Rivero RS, Bracho MA, Castellanos SM, Acurero E, Calchi L M, et al. Prevalencia de enteroparásitos en niños de la etnia Yukpa de Toromo, Estado Zulia, Venezuela. Rev. Méd. Chile. 2006; 134(1): 72-78.

29. Organización Mundial de la Salud. Enfermedades Parasitarias Intestinales. Informe del Comité de Expertos de la OMS. Geneva: WHO; 2002. Serie de Informes Técnicos: 327.

30. Organización Mundial de la Salud, Información y análisis de salud: Situación de Salud en las Américas: Indicadores Básicos 2011. Washington, DC. USA, 2011.

31. Wilson WM, Dofour DL, Staten LK, Barac-Nieto M, Reina JC, Spurr GB. Gastrointestinal parasitic infection, anthropometrics, nutritional status and physical work capacity in Colombian boys. Am J Hum Biol. 1999; 11:763-71. 